\title{
Experimental study of the out-of-plane behaviour of masonry infill walls with and without previous in-plane damage
}

\author{
A. Furtado, A. Arêde \& H. Varum \\ CONSTRUCT-LESE, Faculty of Engineering (FEUP), University of Porto, Portugal \\ H. Rodrigues \\ RISCO, School of Technology and Management, Polytechnic Institute of Leiria, Portugal
}

\begin{abstract}
Recent earthquakes demonstrated a significant contribution of the masonry infill walls in the structural response of the existent reinforced concrete buildings. When subjected to seismic actions, they tend to interact with the surrounding RC frames, which can result in different failure modes depending on the combination of the in-plane and the out-of-plane behaviour. From the surveys on damaged and collapsed RC buildings in the L'Aquila (Italy) and Lorca (Spain) earthquakes a large number of buildings that suffered severe damage or collapse had their poor performance associated with the influence of the infill panels. The masonry infill walls are considered non-structural elements but, their contribution should be considered in the structural response analysis of existing buildings, for which the understanding out-ofplane non-linear behaviour of infill walls is of full importance in order to develop efficient strengthening solutions to prevent and improve their performance in future earthquakes, and consequently reduce their seismic vulnerability. The main objective of the present paper was to obtain further knowledge concerning to the out-of-plane response of masonry infill walls panels. For this an experimental testing campaign on full scale infill walls was carried out in three experimental (cyclic and monotonic) out-of-plane tests with and without previous in-plane damage. The experimental campaign, material characterization and the test setup will be described along the manuscript as well as the main experimental tests results will be presented and discussed.
\end{abstract}

\section{INTRODUCTION}

In recent years, interest has increased in the study of infill masonry (IM) walls, namely in their influence on the seismic response of existing buildings. The contribution of the presence of IM to a building's seismic performance can be favourable or unfavourable, depending on a series of phenomena detailing aspects and mechanical properties, such as the relative stiffness and strength between the frames and the IM walls, the type of connection between the IM and the structures, etc. (Fardis, 1996, Dolsek and Fajfar, 2008, Ricci et al., 2011, Hermanns et al., 2014, Penna et al., 2014, Luca et al., 2014, Asteris et al., 2011, Furtado et al., 2015d, Furtado et al., 2015b).

One of the most critical failures is the out-ofplane infill (Figure 1), and the major factors that causes the out-of-plane instability and poor performance is the deficient/insufficient supportwidth of the RC beams and/or slabs, normally adopted to minimize the thermal-bridge effect, with no connection between the interior and the exterior panels and, finally, no connection to the

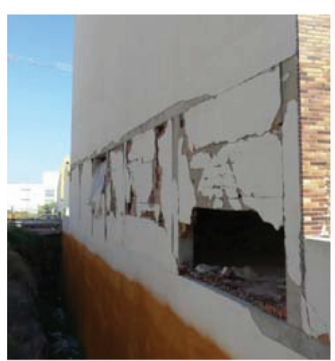

a)

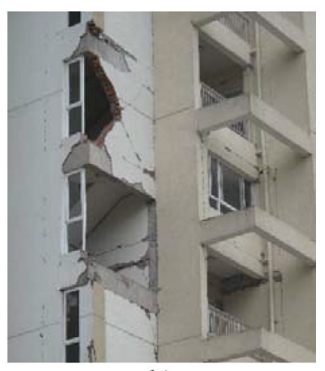

b)
Figure 1. Out-of-plane collapse of IM walls after: a) Lorca (Spain) earthquake in 2011; and b) Ghorka (Nepal) earthquake in 2015.

surrounding RC frames (Vicente et al., 2012, Furtado et al., 2015c, Furtado et al., 2016).

It is consensual that further and deeper knowledge is required of the out-of-plane behaviour of IM walls to develop effective retrofit strategies that prevent this type of collapse and consequently protect the buildings' users' safety, as well as that of 
people near the building. The study of this type of collapse mechanism is also important to support the development of accurate numerical models that represent the expected behaviour of IM walls subjected to out-of-plane loadings, combined or not with in-plane loadings.

Thus, the experimental test appears to be an excellent tool that allows the study of IM walls subjected to static or dynamic cyclic experimental tests combining different types of test variation, such as: evaluation of the out-of-plane performance with different in-plane damage levels, variations in the dimensions of the IM walls, different types of masonry bricks, etc. However this type of experimental test is difficult to perform as it requires complex experimental set-ups with sufficient capacity for large samples. Some experimental studies have been carried out in order to characterize the outof-plane performance of the infill panels considering and ignoring previous in-plane damage (Calvi and Bolognini, 2001, Hak et al., 2014, Akhoundi et al., 2015). From the experimental studies it was observed that the out-of-plane capacity of the IM walls is reduced with the increase in in-plane demands, leading to the conclusion that further experimental investigations, mainly of specimens representative of the country's building stock, are of extreme importance.

Based on this motivation, an experimental campaign was undertaken with the main goal of characterizing the out-of-plane behaviour of infilled RC frames. Full-scale experimental tests were undertaken at the Laboratory of Earthquake and Structural Engineering - LESE, with the geometry based on a previous statistical study conducted into Portuguese RC building stock, namely buildings constructed in the 1960's and 70's (Furtado et al., 2015a). The results of the experiments comprising three out-of-plane tests (with and without previous in-plane damage) will be presented and also discussed in terms of hysteretic force-displacement curves and cracking pattern.

\section{EXPERIMENTAL CAMPAIGN OF MASONRY INFILL WALLS OUT-OF-PLANE TESTS}

\subsection{General overview and main objectives}

The present experiments comprised three out-ofplane tests of full-scale infilled RC frames, two of them without previous in-plane damage and one with previous in-plane damage. The general dimensions of the specimens were selected as $4.80 \times 3.30 \mathrm{~m}$ and the cross sections of the RC columns and beams were $0.30 \times 0.30 \mathrm{~m}$ and $0.30 \times 0.50 \mathrm{~m}$, respectively, which are representative of those existing in the Portuguese building stock (Furtado et al., 2015a).

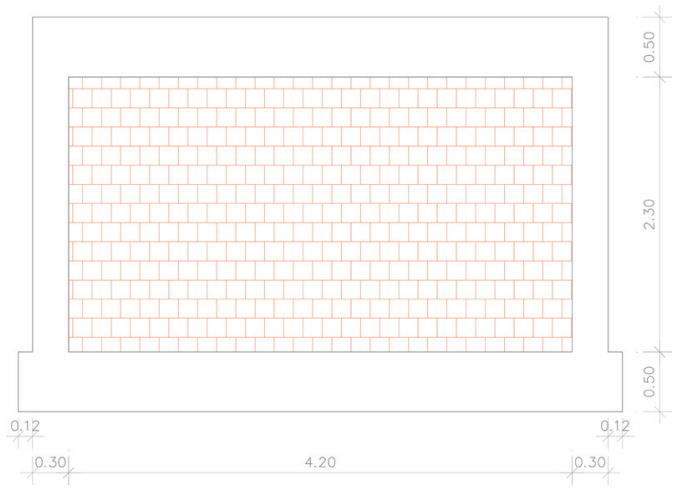

Figure 2. Infilled RC frame specimen general dimensions (in meters).

Figure 2 shows the RC infilled frame geometry. All infill panels have equal geometry with in-elevation dimensions of $2.30 \times 4.20 \mathrm{~m}$ made of horizontal hollow clay bricks, as usually found in the most common masonry in Portugal. No reinforcement was used to connect the infill panel and the surrounding RC frame. Three infill panels were built (denoted as Inf_01, Inf_02 and Inf_03), all having an external leaf (150 $\mathrm{mm}$ thick) aligned with the external side of the RC beam. For the panel Inf_03, an internal leaf, $110 \mathrm{~mm}$ thick, was added aligned with internal side of the beam, leaving a hollow thickness of $40 \mathrm{~mm}$. This double-leaf panel was first tested for in-plane cyclic displacements, after which the internal leaf was removed, leaving the external leaf to be tested under the same out-ofplane loading conditions as for panel Inf_02.

Along the present manuscript only the out-ofplane tests details and results will be presented. Further information about the in-plane tests setup, loading condition and main results are described in (Furtado et al., 2016).

\subsection{Material characterization}

The material ordered for the RC frame specimen construction consisted of regular C20/25-class, and from the compression an and tension strength tests it was obtained a mean compressive strength of the concrete of $\mathrm{f}_{\mathrm{cm} \text {.cyl }}=21.4 \mathrm{MPa}$ with an elastic modulus of Ec,cil = $24.7(\mathrm{GPa})$. For the columns' construction it was used A500 steel class rebars, with Young modulus of $\mathrm{E}=209.4 \mathrm{GPa}$, yielding strength $\mathrm{F}_{\mathrm{sy}}=409.4 \mathrm{MPa}$ and ultimate strength of $\mathrm{F}_{\mathrm{su}}=615 \mathrm{MPa}$. Regarding the masonry properties a traditional mortar type M5 was used on the wall construction process. Vertical strength and diagonal tensile strength tests were performed in order to characterize the masonry properties and it 
was obtained $\mathrm{f}_{\mathrm{m}}=0.531 \mathrm{MPa}$ and $\mathrm{f}_{\mathrm{md}}=0.303 \mathrm{MPa}$ respectively.

\subsection{Out-of-plane test setup description}

The out-of-plane test consisted of the application of a uniformly distributed surface load through a system composed of seven nylon airbags, reacting against a self-equilibrated steel structure, as shown in Figure 3. The application of a uniform out-of-plane loading pretends (as was observed) to globally mobilize the out-of-plane response of the IM wall. In the literature similar out-of-plane load distribution adopted by other authors can be found (Griffith et al., 2007, Ferreira et al., 2015).

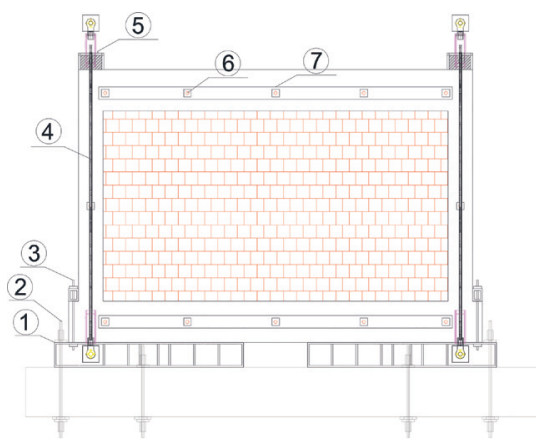

a)

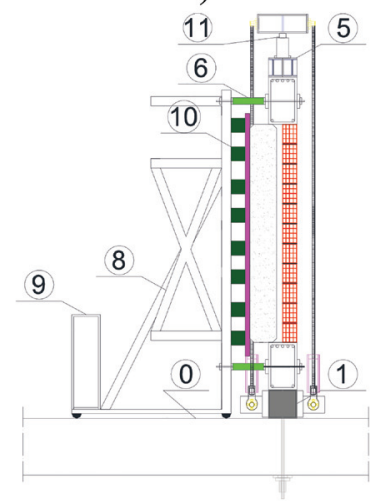

b)

Figure 3. Layout of the out-of-plane test setup: a) Front view; and b) Lateral view. 0 - strong floor, 1 - foundation steel shape, 2 - high-strength rods ( $\varnothing 30 \mathrm{~mm})$ fixing the foundation steel shape to the reaction slab, 3 - steel rod $(\varnothing 20 \mathrm{~mm})$ connecting the $\mathrm{RC}$ frame to the foundation steel shape, 4 - vertical high-strength rods $(\varnothing 30 \mathrm{~mm})$ to apply axial load, 5 - steel cap, 6 - steel rods $(\varnothing 20 \mathrm{~mm})$ connecting the $\mathrm{RC}$ frame and the reaction structure, 7 - distributing load plate, 8 - self-equilibrated reaction steel structure, 9 - counterweight, 10 - wood bars, 11 hydraulic jack (for axial load application), 12 - vertical wooden platform, 13 - airbags, 14 - infill panel, 15 - RC column, 16 - steel plate for rod force distribution.
This reaction structure is composed by five vertical and four horizontal alignments of rigidly connected steel bars, in front of which a vertical wooden platform is placed to resist the airbag pressure and transfer it to the steel reacting grid elements. Thus, 12 steel threaded rods, crossing the RC elements in previously drilled holes, were used to equilibrate the reaction force resulting from the pressure applied by the airbags in the infill panel. The steel rods were strategically placed to evaluate the load distribution throughout the entire infilled $\mathrm{RC}$ frame resorting to load cells attached to each rod, which allowed continuous measurement of the forces transmitted to the reaction structure to which the rods were directly screwed. On the other extremity of each tensioned rod, appropriate nuts and steel plates were used to anchor the rod and apply its reaction force to the concrete surface by uniformly distributed normal stresses, thus avoiding load concentration on the $\mathrm{RC}$ elements crossed by the rods.

In each column, the axial load was applied by means of a hydraulic jack inserted between a steel cap placed on the top of the column and an upper HEB steel shape, which, in turn, was connected to the foundation steel shape resorting to a pair of high-strength rods per column. Hinged connections were adopted between these rods and the top and foundation steel shapes; the axial load actually applied to the columns was continuously measured by load cells inserted between the jacks and the top of each column, which was paramount in performing the in-plane tests.

The pressure level inside the airbags was set by two pressure valves which were controlled according to the target and measured out-of-plane displacement of the central point of the infill panel (the control node and variable) continuously acquired during the tests using a data acquisition and control system developed in the National Instruments LabVIEW software platform (NI, 2012). Prior to the experiments, calibration of the whole system was undertaken; this consisted of comparing the sum of the load cell forces with the airbag pressure resultant force (the pressure multiplied by the theoretical loaded panel area), in order to obtain the variation of load distribution, i.e. indirectly the actually loaded area, with the increase in distance between the steel reaction structure and the surface loaded panel. This calibration was achieved by inserting a vertical wooden panel supported in wood beams reacting against the $\mathrm{RC}$ top and bottom beams, thus without involving the brick masonry panel. In Figure 4 it is presented the general view of the out-of-plane test setup.

\subsection{Loading condition}

The main objective of the present experiments is to better understand the out-of-plane behaviour of 


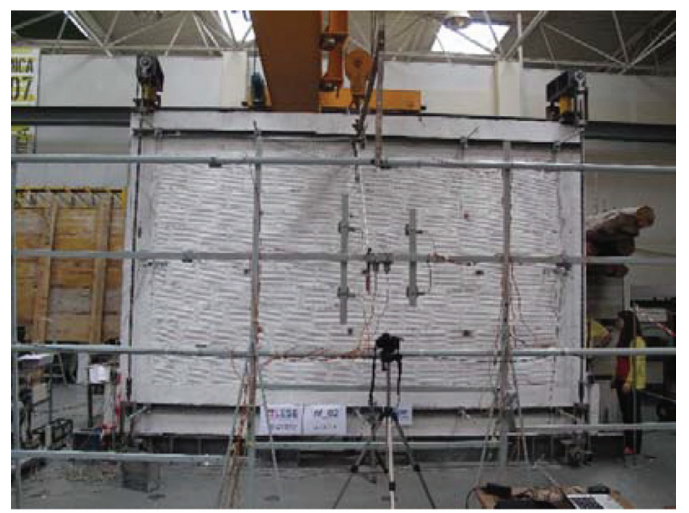

a)

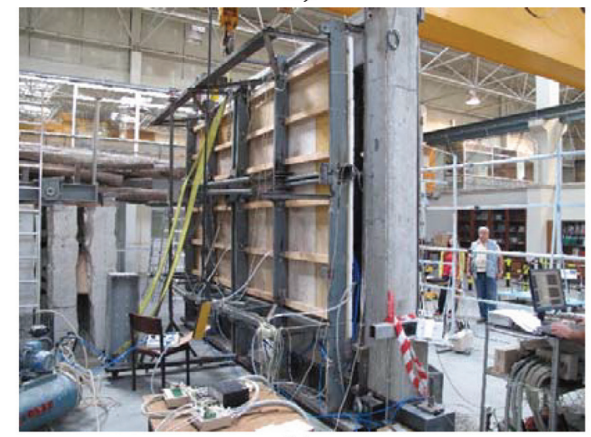

b)

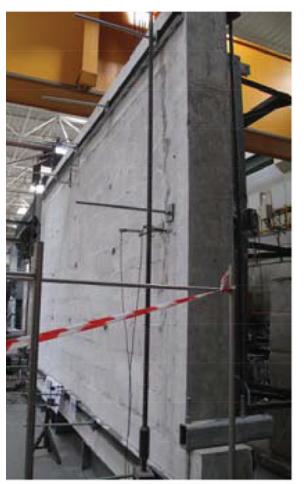

c)

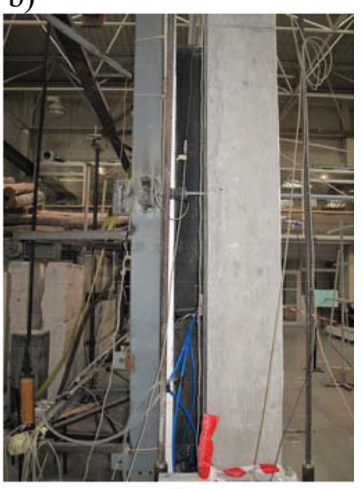

d)
Figure 4. General view of the out-of-plane test setup: a) Front view; b) back view; c) Lateral view; and d) detail of the out-of-plane loading application.

IM walls, particularly when subjected to previous in-plane damage. In addition, the assessment of the influence of the RC column axial load application in the out-of-plane response was made possible by imposing an axial load of $300 \mathrm{kN}$ on each $\mathrm{RC}$ column during the test on Inf_01 and no axial load during tests on Inf_02 and Inf_03. Inf_03, comprising a double-leaf panel, was first subjected to an in-plane drift of $0.5 \%$, and then the interior panel was removed and the damaged external panel was subjected to out-of-plane loading.

The Inf_01 test was carried out by imposing monotonic increasing out-of-plane displacements in the IM panel. With regard to the Inf_02 and Inf_03 tests, cyclic out-of-plane displacements were imposed on the IM wall with steadily increasing displacement levels, targeting the following nominal peak displacements: $2.5 ; 5 ; 7.5 ; 10 ; 15 ; 20$; $25 ; 30 ; 35 ; 40 ; 45 ; 50 ; 50 ; 55 ; 60 ; 65$ and $70(\mathrm{~mm})$. Three cycles were repeated for each lateral deformation demand level at the control node chosen as the central point of the IM wall where concentrated deformation is expected.

\section{OUT-OF-PLANE TESTS RESULTS}

\subsection{Original non-damaged IM walls}

The main results of the out-of-plane tests of the fully infilled RC frames, Inf_01 and Inf_02, were evaluated in terms of shear-drift hysteretic curves, out-of-plane displacement profiles and damage evolution and crack pattern.

\subsubsection{Force-drift hysteretic}

The maximum strength was almost four times higher for the tests without previous in-plane damage (In_01 and Inf_02) and for higher out-of-plane drift values. For the Inf_01 and Inf_02 tests the maximum strength occurs for out-of-plane drift values of $1.5-2 \%$ as illustrated in Figure 5.

The strength degradation is particularly pronounced in both tests. This fact can be explained by the failure mode observed in this test (described below). In the monotonic test between the displacement of $40 \mathrm{~mm}$ and $70 \mathrm{~mm}$ it is observed a linear range which is explained by the brittle collapse observed at the $40 \mathrm{~mm}$ approximately. By comparing Inf_01 and Inf_02, it was also verified that the initial stiffness of the IM walls was slightly affected by the axial loading in the RC columns. Namely, it was verified that the test with axial load (Inf_01) had about 5\% more initial stiffness when compared with Inf_02. It was also verified that the initial cracking for the lower out-of-plane drift values for the Inf_02 was about $10 \%$. The cracking force in both experimental tests was about $50 \mathrm{kN}$.

\subsubsection{Cracking pattern}

Aiming for a detailed observation of the damage evolution during the experimental tests, within the present study each test was stopped at the end of the last cycle of each displacement level in order to highlight and register new cracks and/or the evolution of existing cracks. The final cracking shape 


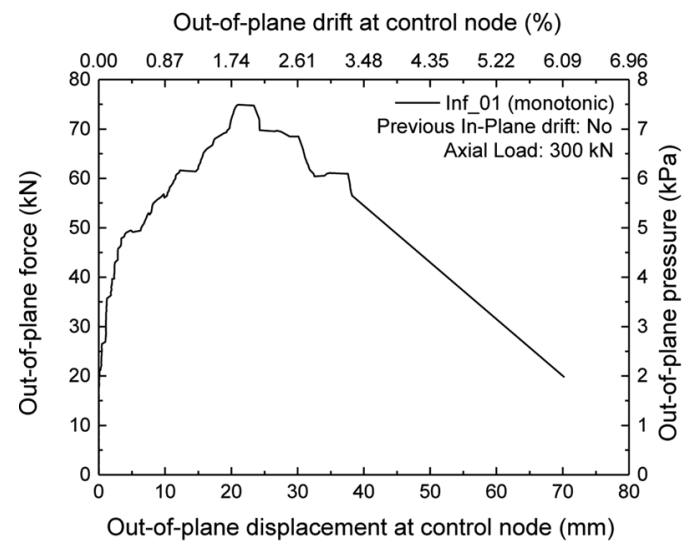

a)

Out-of-plane drift at control node (\%)

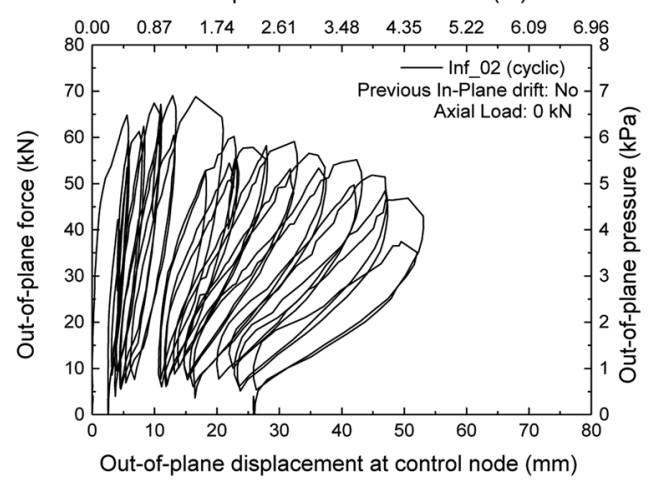

b)

Figure 5. Original and non-damaged IM wall forcedrift results: a) monotonic test Inf_01 and b) cyclic test Inf_02.

of Inf_01 was vertical, with detachment between the infill panel and the surrounding $\mathrm{RC}$ frame in the top and bottom joints, as shown in Figure 6a. However, the Inf_02 test exhibited a trilinear cracking pattern with deformation concentrated in the mid-point of the wall, with slight cracking in the top joint (Figure 6b). This difference could be justified by the axial load applied in the columns during the monotonic test that changed the border restrains of the original panel ore due to testing procedure (monotonic and cyclic load). Further tests will be performed in the future to understand the relationship between the cracking pattern and the load condition.

\subsection{IM wall with previous in-plane damaged}

The main results of the out-of-plane tests of the IM wall with previous in-plane damaged $(0.5 \%$ previous in-plane drift), Inf_03 are presented in terms of force-drift hysteretic curves and cracking pattern.

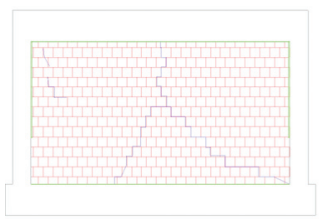

a)

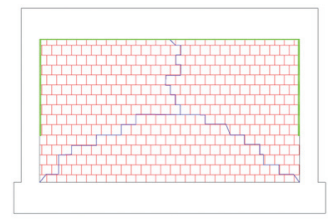

b)
Figure 6. Original and non-damaged IM wall cracking pattern: a) monotonic test Inf_01 and b) cyclic test Inf_02.

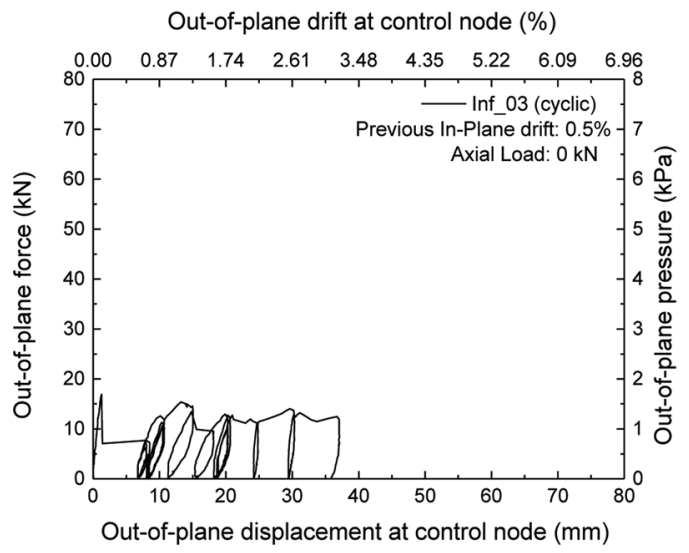

Figure 7. IM wall with previous in-plane damaged (Inf_03) force-drift results.

\subsubsection{Force-drift hysteretic}

Concerning the tests without previous in-plane damage, initial cracking was found for the lower out-of-plane drift values (about $0.1 \%$ drift) for the Inf_02 test. The cracking force in both experimental tests was about $50 \mathrm{kN}$. In the test with previous in-plane damage (Inf_03), initial cracking occurred at $0.1 \%$ drift and at a maximum strength of $18 \mathrm{kN}$, as shown in Figure 7.

\subsubsection{Cracking pattern}

Finally, no cracking pattern occurred in the middle of the IM wall Inf_03, which is related to the observed detachment between the infill panel and the surrounding top beam and columns, evidencing typical rigid body behaviour, as illustrated in Figure 8.

\subsection{Global results}

Through comparison between the force-displacement hysteretic curves, a significant difference between the test results, with and without previous in-plane damage can be observed, namely: a) the 


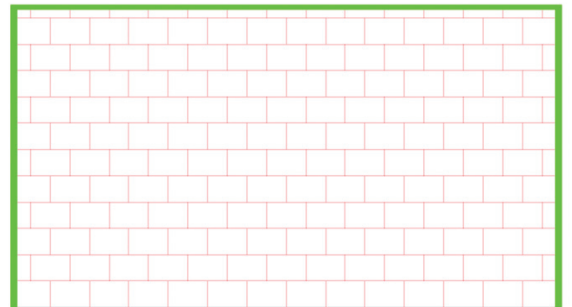

Figure 8. IM wall with previous in-plane damaged (Inf_03) cracking pattern.

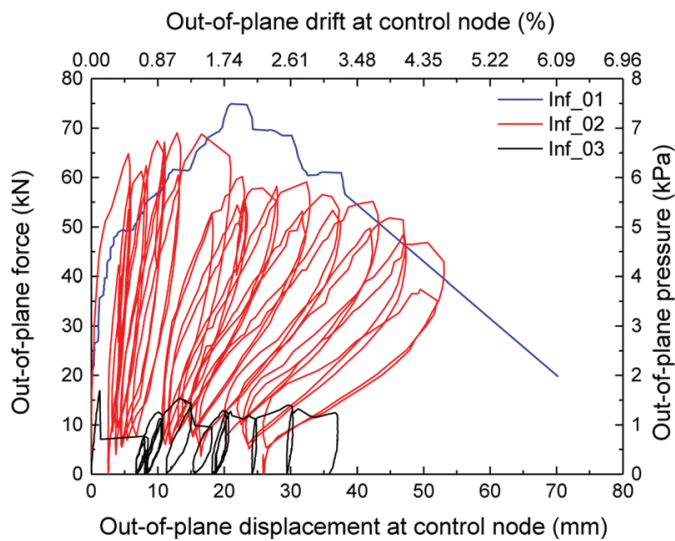

Figure 9. Global results: force-drift.

maximum strength was almost four times higher for the tests without previous in-plane damage and for higher out-of-plane drift values; b) the initial stiffness was significantly affected by the introduction of the in-plane damage, that of the test with previous in-plane damage (Inf_03) being almost $30 \%$ lower than the original IM walls; c) a significant maximum strength reduction was found in the tests without the previous in-plane damage, which was not verified in Inf_03 (Figure 9).

The failure modes observed in each of the tests reveal different out-of-plane behaviour of the IM walls with and without previous in-plane damage. The tests of the original IM walls (Inf_01 and Inf_02) showed vertical cracking, with detachment between the infill panel and the surrounding RC frames in the top and bottom joints (Figure 10).

In the Inf_02 wall, trilinear cracking was observed with concentrated deformation in the middle point of the wall, with slight cracking in the top joint. For the test with previous in-plane damage, only detachment was observed between the

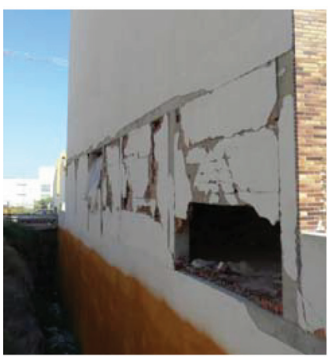

a)

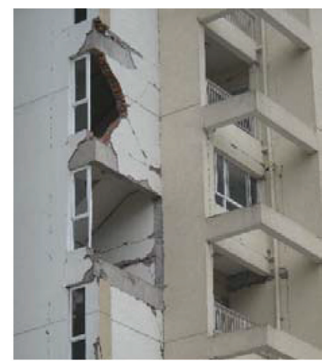

b)
Figure 10. Global results: final damaged a) Inf_01.
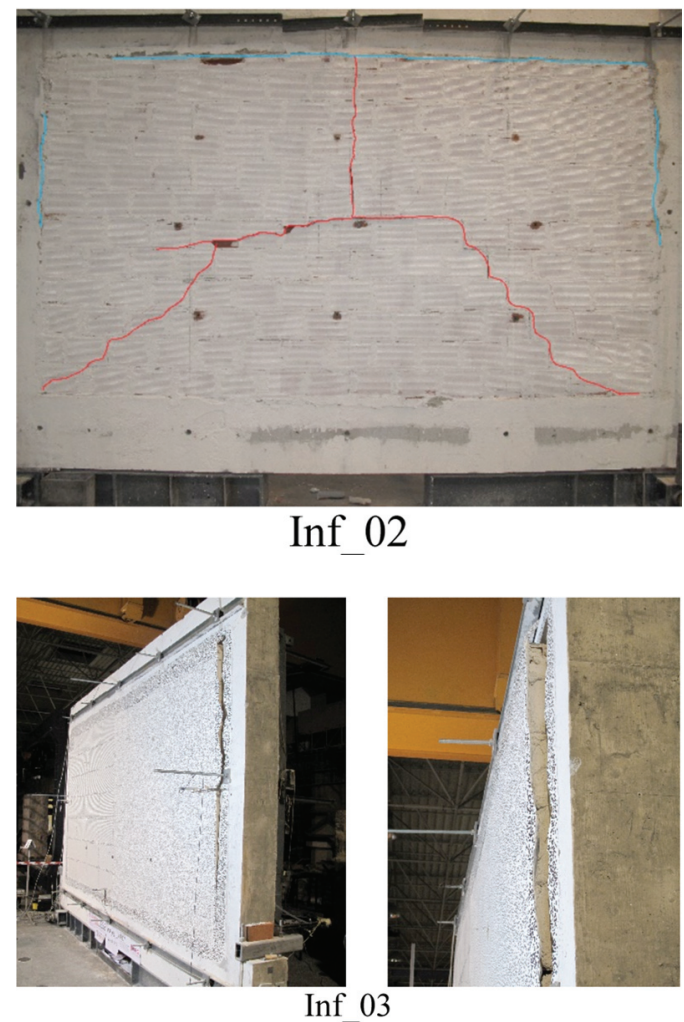

Figure 11. Global results: final damaged a) Inf_02 and Inf_03.

infill panel and the surrounding top beam and columns, and typical rigid body behaviour was found (Figure 11a and Figure $11 \mathrm{~b}$ respectively)

\section{CONCLUSIONS}

This paper reports an experimental campaign carried out at the LESE laboratory at the Faculty of Engineering of the University of Porto in order to 
study the out-of-plane behaviour of IM walls, and the influence of the previous in-plane drift in their out-of-plane response. For this, three full-scale infill panels were constructed and were subjected to out-of-plane monotonic and cyclic loading, with and without previous in-plane drift.

A significant difference was found between the test results, with and without previous in-plane damage, namely: a) the maximum strength was almost four times higher for the tests without previous in-plane damage and for higher out-of-plane drift values; b) a significant reduction in the initial stiffness was observed in the test with previous in-plane damage when compared with the others; c) a significant maximum strength reduction was found in the tests without the previous in-plane damage, which was not verified in the test with prior in-plane damage.

It was also observed that application of the axial load in the columns reduced the infills initial stiffness and introduced a different cracking pattern.

The failure modes observed in each of the tests reveal a different out-of-plane behaviour of the IM walls with and without previous in-plane damage. The tests on original IM walls showed vertical cracking, with detachment between the infill panel and the surrounding $\mathrm{RC}$ frame in the top and bottom joints. For the test with previous in-plane damage, detachment was observed between the infill panel and the surrounding top beam and columns, and typical rigid body behaviour was found.

\section{ACKNOWLEDGMENTS}

The authors would like to acknowledge the technicians of the LESE laboratory, Mr. Valdemar Luis and Mr. Nuno Pinto for their support in the experiments reported in this paper, and Preceram for the provision of all the bricks used in the experiments.

\section{REFERENCES}

Akhoundi, F., Vasconçelos, G., Lourenço, P., Palha, C. \& Martins, A. 2015 Out-of-plane behavior of masonry infill walls. 7th International Conference on Seismology \& Earthquake Engineering. Tehran, Iran.

Asteris, P., Antoniou, S., Sophianopoulos, D. \& Chrysostomou, C. 2011 Mathematical Macromodeling of Infilled Frames: State of the Art. Journal of Structural Engineering, 137, 1508-1517.

Calvi, G. \& Bolognini, D. 2001 Seismic response of reinforced concrete frames infilled with weakly reinforced masonry panels. Journal of Earthquake Engineering, 5, 153-185.

Dolsek, M. \& Fajfar, P. 2008 The effect of masonry infills on seismic response of a four storey reinforced con- crete frame - a probabilistic assessment. Engineering Structures, 30, 1991-2001.

Fardis, M. 1996 Experimental and numerical investigations on the seismic response of RC infilled frames and recommendations for code provisions ECOEST/ PREC 8. Lisbon, LNEC.

Ferreira, T., Costa, A. A., Arêde, A., Gomes, A. \& Costa, A. 2015 Experimental characterization of the out-ofplane performance of regular stone masonry walls, including test setups and axial load influence. Bulletin of Earthquake Engineering, 13, 2667-2692.

Furtado, A., Costa, C., Arêde, A. \& Rodrigues, H. 2015a Geometric characterisation of Portuguese RC buildings with masonry infill walls. European Journal of Environmental and Civil Engineering, pp. 1-16.

Furtado, A., Rodrigues, H. \& Arêde, A. 2015b Modelling of masonry infill walls participation in the seismic behaviour of RC buildings using OpenSees. International Journal of Advanced Structural Engineering (IJASE), 7.

Furtado, A., Rodrigues, H., Arêde, A. \& Varum, H. 2015c Simplified macro-model for infill masonry walls considering the out-of-plane behaviour. Earthquake Engineering \& Structural Dynamics.

Furtado, A., Rodrigues, H., Arêde, A. \& Varum, H. 2016 Experimental evaluation of out-of-plane capacity of masonry infill walls. Engineering Structures, 111, 48-63.

Furtado, A., Rodrigues, H., Varum, H. \& Costa, A. 2015d Evaluation of different strengthening techniques' efficiency for a soft storey building. European Journal of Environmental and Civil Engineering, 1-18.

Griffith, M., Vaculik, J., Lam, N., Wilson, J. \& Lumantarna, E. 2007 Cyclic testing of unreinforced masonry walls in two-way bending. Earthquake Engineering \& Structural Dynamics, 36, 801-821.

Hak, S., Morandi, P. \& Magenes, G. 2014 Out-of-plane experimental response of strong masonry infills. Second European Conference on Earthquake Engineering and Seismology. Istanbull.

Hermanns, L., Fraile, A., Alarcón, E. \& Álvarez, R. 2014 Performance of buildings with masonry infill walls during 2011 Lorca earthquake. Bull Earthquake Eng, 12, 1977-1997.

Luca, F., Verderame, G., Goméz-Martinez, F. \& PérezGarciía, A. 2014 The structural role played by masonry infills on RC buildings performaces after the 2011 Lorca, Spain, earthquake. Bull Earthquake Eng, 12, 1999-2026.

Ni 2012 National Instruments - LabView software.

Penna, A., Morandi, P., Rota, M., Manzini, C., Porto, F. \& Magenes, G. 2014 Performance of masonry buildings during the emilia 2012 earthquakes. Bull Earthquake Eng, 12, 2255-2273.

Ricci, P., De Luca, F. \& Verderame, G. 2011 6th April 2009 L'Aquila earthquake, Italy: reinforced concrete building performance. Bulletin of Earthquake Engineering, 9, 285-305.

Vicente, R., Rodrigues, H., Varum, H., Costa, A. \& Silva, J. M. 2012 Performance of masonry enclosure walls: lessons learned from recent earthquakes. Earthquake Engineering and Engineering Vibration, 11. 